\title{
PRODUKTIVITAS LAHAN DAN DISTRIBUSI PENDAPATAN BERDASARKAN STATUS PENGUASAAN \\ LAHAN PADA USAHATANI PADI \\ (KASUS DI KABUPATEN KENDAL \\ PROPINSI JAWA TENGAH)
}

\author{
Bagio Mudakir \\ Fakultas Ekonomika dan Bisnis Universitas Diponegoro Semarang \\ E-mail: bagio.mersa@gmail.com
}

\section{Diterima 25 April 2011/Disetujui 9 Juni 2011}

\begin{abstract}
Ownership of farm land usually consistent to land tenure status affect to income distribution. The land tenure status are divided into owner operator, renter (cash tenant), and share-cropper operator (share tenant). The objective of this research were studied comparation of production, efficiency, and income distribution at farming. This research analyze income distribution based on different land tenure and relationship inequality with poverty. This research use survey in data collecting and proportional stratified random sampling to choose sample. Analysis method and hypothesis test implement t-test and F-test from Cobb-Douglas function. The research result showed efficiency and production rate of share-cropper operator was not too bad then owner operator and renter (cash tenant). Land farm tenure has effect to income distribution, farmer who has wider land will have bigger income than other. Income inequality without other income higher than income which include income outside farmer. Other income (outside farming) decrease income inequality.
\end{abstract}

Keyword: farm land, income distribution, Cobb-Douglas function

Situasi ekonomi nasional saat ini di cirikan oleh kecenderungan kearah liberalisasi ekonomi yang sangat agresif. Hampir semua sektor ekonomi rakyat diserahkan dalam mekanisme perdagangan bebas yang begitu massif termasuk pertanian. Dominasi kepentingan imperialis dalam perekonomian Indonesia memaksakan penyerahan kedaulatan atas kekayaan alam (tambang, mineral, hutan, hayati, perikanan, dan sebagainya) dalam kungkungan pemilik modal internasional. Jika di telusuri dari proses sejarah, sejak jaman kolonialisme swasta mulai menjadikan pertanian sebagai lahan untuk menggandakan modalnya.

Status penguasaan lahan pada pokoknya dapat dibagi menjadi tiga, yaitu pemilik penggarap (owner operator), penyewa (cash tenant) dan penyakap atau bagi hasil (share tenant). Status penguasaan lahan yang berbeda secara teoritis akan menentukan tingkat keragaman usaha tani yang berbeda pula. Secara teoritis kedudukan petani penyakap palinglah lemah sehingga akan berpengaruh terhadap keragaan usaha tani, tetapi secara faktual tidaklah tentu demikian yang disebabkan oleh berbagai faktor yang perlu diteliti lebih lanjut.

Tingkat keragaan usaha tani yang dimaksudkan disini meliputi perbedaan tingkat produktivitas lahan dan distribusi pendapatan, yang akhirnya dapat dilihat bagaimana pengaruhnya pada tingkat kemiskinan. Tingkat produktivitas lahan yang dimaksudkan di sini meliputi perbedaan tingkat produktivitas lahan dan distribusi pendapatan, yang pada akhirnya dapat dilihat bagaimana pengaruhnya terhadap tingkat kemiskinan. Tingkat produktivitas lahan yang dimaksudkan berupa bagaimana alokasi penggunaan masukan-masukan yang ada kaitannya dengan keluaran 
yang diperoleh pada suatu status penguasaan lahan tertentu.

Salah satu masalah yang paling berat dan kompleks yang dihadapi Indonesia adalah masalah lahan. Salah satunya dari masalah perlahanan adalah menyangkut status penguasaan lahan yang mengkaitkan banyak petani. Khususnya di pulau Jawa Bali dan beberapa daerah yang berpenduduk padat di pulau-pulau besar di luar jawa, sudah sejak sebelum Indonesia merdeka, masalah lahan sudah diramalkan akan selalu "menghantui" para penentu kebijaksanaan (Mubyarto, 1981). Dilihat dari cara petani menguasai lahan, sebenarnya terjadilah stratifikasi sosial dalam masyarakat. Ongkoham (1984) yang mengadakan penelitian tentang penguasaan lahan di Madiun pada abad XIX, menyebut petani yang menguasai lahan disebut sikep (petani yang memeluk atau menanggung beban lahan). Strata di bawah petani sikep merupakan strata terendah dari petani juga disebut bujang. Numpang atau bujang ini merupakan petani yang mengerjakan lahan yang dikuasai sikep. Makan dan tempat tinggal petani numpang ditanggung sepenuhnya oleh petani sikep. Di samping sikep dan numpang terdapat golongan petani menengah yaitu petani numpang yang telah lama bekerja pada petani sikep dan kemudian menikah, ia diberi bagian lahan dari lahan desa atau lahan persekutuan yang disebut lahan lanyah. Lahan persekutuan ini tidak dikuasai secara tetap oleh petani menengah melainkan digilirkan diantara petani-petani menengah lainnya. Fungsi utama lahan persekutuan itu agaknya untuk mengikat buruh tani supaya menetap di desa tersebut, baik untuk kepentingan persekutuan maupun untuk kepentingan sikep.

Purbayu Budi Santosa (2006) menyatakan perlunya dilakukan pendekatan terhadap kasus-kasus ekonomi di Indonesia dengan pendekatan ekonomi kelembagaan karena masih kacaunya data statistik. Pendekatan ini juga layak perlu dilakukan dalam penelitian pertanian pahan. Sektor pertanian pangan sendiri merupakan sektor strategi untuk mendukung ketahanan pangan nasional dan penanggulangan kemiskinan yang dapat dialami para petani Indonesia.

\section{LANDASAN TEORI}

Boeke (1910, dikutip oleh Mubyarto, 1985) menyatakan pembangunan pertanian dan pembangunan pedesaan berjalan lambat karena pada dasarnya petani adalah kolot, konservatif, tidak kreatif, terle- bih-lebih petani kecil. Akibatnya kemiskinan pedesaan bersumber pada kelambanan petani itu sendiri. Jadi petani miskin karena sikap hidupnya yang statis. Geertz (1963) tidak sependapat dengan Boeke, di mana menurutnya petani menjadi statis karena miskin. Kemiskinan yang terjadi pada petani di sebabkan oleh eksploitasi penjajah yang terlalu lama. Lebih lanjut dia menyatakan kebijaksanaan politik-ekonomi tanam paksa oleh penguasa Kolonial Belanda telah menyebabkan menjadi picu terjadinya proses involusi ("pemungkretan") dan shared property ("berbagi kemiskinan").

Status penguasaan lahan yang berbeda akan menentukan tingkat keragaman usaha tani, yang dalam hal ini meliputi tingkat produktivitas lahan dan distribusi pendapatan yang berlainan pula. Teori dasar yang dapat dipakai untuk menerangkan tingkah laku ekonomi dari petani pemilik- penggarap, petani penyewa dan petani penggarap, adalah teorinya Marshall (1959), yang dikenal juga dengan "The Taxequivalent Approach". Marshall dengan menggunakan analisis marjinal pada bagi hasil tanaman (sharecropping), menyatakan karena petani bagi hasil hanya menerima sebagian produk marjinal dari masukan yang dikeluarkan (dalam hal ini tenaga kerja), maka petani dengan status penguasaan lahan ini tidak punya rangsangan yang cukup untuk an system menggunakan masukan yang dimilikinya sampai pada tingkat efisiensi Pereto.

Pada analisis distribusi pendapatan fungsional adalah menyoroti penggunaan faktor-faktor produksi dalam proses produksi, sedangkan analisis produksi pendapatan personal atau individu ditekankan kepada pemilikan faktor produksi. Pada umumnya teori ekonomi memfokuskan pada analisi distribusi pendapatan fungsional, namun akhir-akhir ini para ahli ekonomi tertarik pada distribusi pendapatan (kekayaan) yang lebih bersifat deskripsi dan analisis statistik (Soewito, 1987). Sedangkan distribusi pendapatan personal merupakan suatu konsep empiris untuk menentukan (menilai) bagaimana pendapatan total populasi itu telah terbagi di antara satuan-satuan penerima pendapatan. Menurut Soejono $(1977,1978)$ terdapat dua cara langsung menilai status distribusi pendapatan sesuatu populasi penerima pendapatan (income recipient), yaitu: (1) penaksiran distribusi persentase pendapatan total yang diterima masing-masing golongan (equal-group percentage distribution), dan (2) penaksiran dengan indikator khusus (summary mea- 


\section{sures/indicators).}

Guna melihat bagaimana distribusi pendapatan personal antar status penguasaan lahan, terlebih dahulu perlu melihat aliran penguasaan lahan yang biasa terdapat (Sawit, 1985). Perhatikan Gambar 3.1 berikut yang akan menjelaskan aliran penguasaan lahan.

\section{Gambar 1. Aliran Penguasaan Lahan}

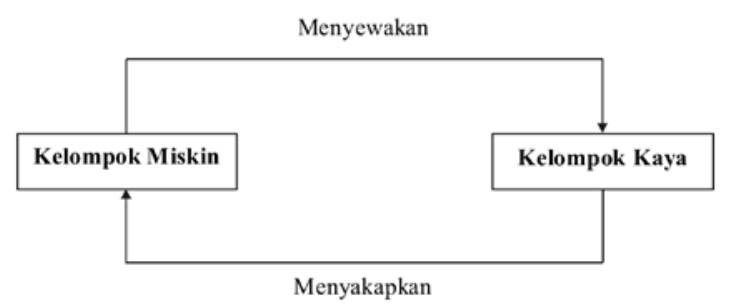

Berdasarkan kepada Gambar 3.1 terlihat bahwa penyakapan (bagi hasil) merupakan pengalihan penguasaan lahan dari kelompok yang relatif kaya kepada kelompok yang relatif miskin, sedangkan persewaan lahan merupakan pengalihan yang berjalan sebaliknya, dari petani yang relatif miskin ke petani yang relative kaya. Jadi dengan mendasarkan kepada fenomena tersebut, diduga distribusi pendapatan personal antara berbagai system penguasaan lahan akan mengalami ketimpangan, di mana terdapat golongan yang relatif kaya (petani pemilik dan penyewa) maupun terdapat golongan yang relatif kurang mampu (petani penyakap).

\section{METODE PENELITIAN}

\section{Hipotesis I}

\section{Subhipotesis 1a}

Status penguasaan lahan penyakap tingkat produksinya paling rendah dibandingkan petani pemilik penggarap dan petani penyewa. Hipotesis yang telah dinyatakan akan diuji dengan memakai uji t maupun F dari fungsi produksi Cobb-Douglas. derajat kepercayaan yang dipakai dalam uji hipotesis pada penelitian ini, masing-masing 90\% ( $\alpha=10 \%), 95 \%(\alpha=5 \%)$, 99\% $(\alpha=1 \%)$. Pemakaian derajat kepercayaan sampai $90 \%$ dengan alasan penelitian ini termasuk penelitian sosial-ekonomi, yang mentolelir derajat kesalahan sampai sebesar 10\% (Mirer, 1990). Adapun fungsi produksi Cobb-Douglas yang dimaksud adalah:

$$
Y=A X_{1}^{a_{1}} X_{2}^{a_{2}} X_{3}^{a_{3}} \ldots X_{8}^{a} e\left(\mathrm{U}+\mathrm{E}_{j} \sum_{j=1}^{2} D_{j}\right)
$$

Persamaan (1) dapat dirubah dalam bentuk li- nier yang bentuknya menjadi sebagai berikut:

$$
\begin{aligned}
\ln Y= & \ln A+\alpha_{1} \ln X_{1}+\alpha_{2} \ln X_{2}+\alpha_{3} \ln X_{3}+\alpha_{4} \ln X_{4} . \\
& +\alpha_{5} \ln X_{5}+\alpha_{6} \ln X_{6}+\alpha_{7} \ln X_{7}+\alpha_{8} \ln X_{8}+U \\
& +E_{j} D_{j} \quad \ldots \ldots \ldots \ldots \ldots \ldots \ldots \ldots \ldots \ldots \ldots \ldots \ldots \ldots \ldots \ldots \ldots \ldots \ldots \ldots \ldots \ldots \ldots \ldots \ldots \ldots \ldots \ldots
\end{aligned}
$$

dimana: $\mathrm{Y}$ adalah produksi padi., $\mathrm{A}=$ intersep, $\mathrm{X}_{1}=$ jumlah benih padi $(\mathrm{kg}), \mathrm{X}_{2}=$ jumlah pupuk urea $(\mathrm{kg})$, $\mathrm{X}_{3}=$ jumlah pupuk TSP $(\mathrm{kg}), \mathrm{X}_{4}=$ jumlah pupuk lainnya $(\mathrm{kg}), X_{5}=$ jumlah pestisida (linier), $X_{6}=$ jumlah tenaga kerja (orang), $X_{7}=$ luas lahan (m2), $X_{8}=$ pengeluaran lainnya (rp), Ej= koefisien variabel boneka (dummy), Dj= variabel boneka status penguasaan lahan; D1=1 untuk status pemilik, D1=0 untuk status status penguasaan lahan lainnya; D2 $=1$ untuk status penyewa, D2=0 untuk status lainnya.

\section{Subhipotesis $1 b$}

Status penguasaan lahan penyakap tingkat efisiensinya paling rendah dibandingkan petani pemilik penggarap dan petani penyewa. Subhipotesis $1 \mathrm{~b}$ ini menggunakan model fungsi keuntungan Cobb-Douglas (UOP/Unit Output Price). Dalam menggunakan fungsi keuntungan ini dilakukan dengan memasukan tujuan masukan tetap (variabel input). Adapun model persamaan fungsi keuntungan Cobb-Douglas adalah:

$$
\begin{aligned}
\ln \pi_{a}= & \ln A^{*}+a_{1}^{*} \ln w_{1}+a_{2}^{*} \ln w_{2}+a_{3}^{*} \ln w_{3}+ \\
& a_{4}^{*} \ln w_{4}+a_{5}^{*} \ln w_{5}+a_{6}^{*} \ln w_{6}+\beta_{1}^{*} \ln z_{1}+ \\
& \beta_{2}^{*} \ln z_{2} \ldots \ldots \ldots \ldots \ldots \ldots \ldots \ldots \ldots \ldots \ldots \ldots \ldots \ldots \ldots \ldots \ldots \ldots \ldots \ldots \ldots \ldots \ldots \ldots \ldots \ldots \ldots
\end{aligned}
$$

dimana: $\ln \Pi_{\mathrm{a}}=$ Keuntungan $U O P$ jangka pendek yang dinormalkan (dibagi) harga padi, $\mathrm{A}^{*}=$ Konstanta, $\mathrm{W}_{1}=$ Harga benih padi yang dinormalkan harga padi , $\mathrm{W}_{2}=$ Harga pupuk urea yang dinormalkan harga padi, $\mathrm{W}_{3}=$ Harga pupuk TSP yang dinormalkan harga padi, $\mathrm{W}_{4}=$ Harga pupuk lain yang dinormalkan harga padi, $\mathrm{W}_{5}=$ Harga pestisida per liter yang dinormalkan harga padi, $\mathrm{W}_{6}=$ Tingkat harga (upah) tenaga kerja yang dinormalkan harga padi, Z1= Luas lahan usaha tani (m2), Z2=Pengeluaran lainnya (rupiah), $\mathrm{a}_{\mathrm{i}}^{*}=\mathrm{Pa}-$ rameter masukan bebas yang diduga, $i=1, \ldots 6,{ }_{\beta}^{*}=$ Parameter masukan tetap yang diduga, $i=1,2$

\section{Hipotesis 2}

Ketimpangan dalam distribusi pendekatan personal diduga akan makin memperbesar tingkat kemiskinan yang dialami petani. Cara pengujian hipotesis ketiga dilakukan dengan cara menghitung proporsi petani yang hidup miskin, kemudian proporsi petani miskin tersebut dikorelasikan dengan angka indeks 
gini pada keseluruhan petani. Analisis korelasi sederhana digunakan dalam pengujian hipotesis ketiga.

\section{HASIL DAN PEMBAHASAN}

\section{Profil Sosial Ekonomi Responden}

Bedasarkan wawancara dan penelitian lapangan kepada 121 responden, maka didapatkan hasil bahwa rata-rata umur responden adalah 50 tahun dengan responden terbanyak adalah responden yang berumur antara 40 sampai dengan 69 tahun. Pendidikan responden terbanyak adalah lulusan SD atau SR (sekolah rakyat). Dari keseluruhan sampel petani yang telah diwawancarai dapat ditarik kesimpulan bahwa hampir semua responden menyatakan bahwa pertanian merupakan sumber pendapatan utama kemudian ada juga yang mempunyai pekerjaan sampingan lain selain bertani.

Pengertian pemilikan dan penguasaan lahan biasanya dibedakan. Pemilikan lahan mempunyai pengertian seseorang yang secara hukum dibenarkan (de jure) mempunyai sebidang lahan. Adapun penguasaan lahan adalah seseorang yang secara nyata (de fakto) mengerjakan sebidang lahan, baik yang dilakukan oleh pemilik lahan sendiri, secara sewa maupun bagi hasil. Dengan demikian seseorang yang memiliki lahan belum tentu mengerjakan lahan untuk usahatani, sedangkan seseorang yang menguasai lahan diartikan dengan seseorang yang mengerjakan lahan tersebut. Untuk mengetahui bagaimana proporsi pemilikan lahan di daerah penelitian, perhatikan Tabel 1.
Sedangkan untuk distribusi pemilikan lahan di Desa Rowosari Kecamatan Rowosari Kabupaten Kendal dapat dilihat dalam Tabel 2.

\section{Penggunaan Faktor-Faktor Produksi}

Tenaga kerja adalah salah satu faktor produksi yang utama. Dalam usahatani kedudukan si petani dalam usahatani sangat penting. Petani dalam usaha tani tidak hanya menyumbangkan tenaga saja, tapi lebih dari pada itu, Petani adalah pemimpin (manager) usaha tani, mengatur organisasi produksi secara keseluruhan. Salah satu faktor yang memiliki tingkat produktifitas adalah lahan garapan. Hal ini menyebabkan usaha pertanian yang mempunyai tanah sedikit di daerah tertentu produksinya atau pendapatan yang diperoleh juga sedikit. Dapat dikatakan pula bahwa luas tanah berpengaruh positif terhadap hasil atau produksi. Semakin luas lahan sawah hasil yang diperoleh semakin tinggi. Begitu juga sebaliknya semakin sempit luas lahan yang digunakan untuk berusahatani maka produksi yang dihasilkan juga sedikit.

Penggunaan benih unggul oleh para petani dapat meningkatkan produksi hasil usahatani. Jenis benih yang digunakan oleh petani di daerah penelitian adalah jenis benih situbagendit, Conde, IR 64, Cisadane dan Cihera. Rata-rata penggunaan benih oleh 121 responden di daerah penelitian di musim kemarau dan penghujan berbeda. Pupuk yang digunakan oleh petani di daerah penelitian beragam. Ada yang memakai pupuk jenis Urea, pupuk TSP, pupuk NPK, pupuk ZA dan ada yang ditambah pupuk organik. Berbagai macam pupuk ini digunakan untuk 2 kali pemupukan

Tabel 1. Pemilikan Lahan Sawah Oleh Responden

\begin{tabular}{|c|l|r|r|r|r|}
\hline \multirow{2}{*}{ No } & \multirow{2}{*}{ Keterangan } & \multicolumn{2}{c|}{ Musim Kemarau } & \multicolumn{2}{c|}{ Musim Penghujan } \\
\cline { 3 - 6 } & & \multicolumn{1}{c|}{ Jumlah } & \multicolumn{1}{c|}{ Persentase } & \multicolumn{1}{c|}{ Jumlah } & \multicolumn{1}{c|}{ Persentase } \\
\hline 1 & Memiliki lahan sawah & 73 & 60,33 & 73 & 60,33 \\
\hline 2 & Tidak memiliki lahan & 48 & 39,67 & 48 & 39,67 \\
\hline \multicolumn{2}{|l}{ Jumlah responden } & 121 & 100 & 121 & 100 \\
\hline
\end{tabular}

Sumber: Data Primer diolah, 2009

Tabel 2. Distribusi Pemilikan Lahan Sawah Pada Musim Kemarau dan Penghujan

\begin{tabular}{|c|l|c|c|}
\hline No & \multicolumn{1}{|c|}{ Luas kepemilikan $(\mathrm{Ha})$} & Musim Kemarau & Musim Penghujan \\
\hline 1 & $\geq 1 / 3$ lupit $(0,3 \mathrm{Ha})$ & 72 & 72 \\
\hline 2 & $\leq 1 / 3$ lupit $(0,3 \mathrm{Ha})$ & 49 & 49 \\
\hline \multicolumn{2}{|c|}{ Rata-rata pemilikan } & $0,53 \mathrm{Ha}$ & $0,53 \mathrm{Ha}$ \\
\hline
\end{tabular}

Sumber: Data Primer diolah, 2009 
Tabel 3. Rata-rata penggunaan faktor-faktor produksi pada musim penghujan

\begin{tabular}{|c|l|c|c|c|}
\hline No & \multicolumn{1}{|c|}{ Faktor Produksi } & Pemilik & Penyewa & Penyakap \\
\hline 1 & Benih (kg) & 23,06 & 13,93 & 10,25 \\
\hline 2 & Pupuk Urea (kg) & 236,85 & 98,12 & 76,62 \\
\hline 3 & Pupuk TSP (kg) & 182,50 & 41,87 & 33,33 \\
\hline 4 & Pupuk lain (Kg) & 81,18 & 35,31 & 0 \\
\hline 5 & Pestisida (liter) & 0,57 & 0,48 & 0,26 \\
\hline 6 & Tenaga Kerja (orang) & 41,42 & 27,66 & 21,29 \\
\hline
\end{tabular}

Sumber: Data Primer diolah, 2009

Tabel 4. Rata-rata penggunaan faktor-faktor produksi pada musim Kemarau

\begin{tabular}{|c|l|c|c|c|}
\hline No & \multicolumn{1}{|c|}{ Faktor Produksi } & Pemilik & Penyewa & Penyakap \\
\hline 1 & Benih $(\mathrm{kg})$ & 23,03 & 13,97 & 10,21 \\
\hline 2 & Pupuk Urea $(\mathrm{kg})$ & 246,85 & 102,71 & 79,71 \\
\hline 3 & Pupuk TSP $(\mathrm{kg})$ & 211,36 & 50,55 & 100 \\
\hline 4 & Pupuk lain $(\mathrm{Kg})$ & 83,89 & 35,31 & 30 \\
\hline 5 & Pestisida (liter) & 0,54 & 0,47 & 0,25 \\
\hline 6 & Tenaga Kerja (orang) & 41,42 & 27,75 & 21,29 \\
\hline
\end{tabular}

Sumber: Data Primer diolah, 2009

yaitu pada saat akan penanaman dan saat perawatan tanaman. Rata-rata penggunaan berbagai macam pupuk tersebut di musim penghujan dan kemarau berbeda.

Untuk lebih jelasnya mengenai rata-rata penggunaan faktor-faktor produksi pada musim penghujan ddan musim kemarau di Desa Rowosari Kecamatan Rowosari Kabupaten Kendal akan disajikan ke dalam Tabel 3. Sedangkan Tabel 4 merupakan rata-rata penggunaan faktor produksi pada musim kemarau di

daerah penelitian

\section{Biaya dan Pendapatan Usahatani}

Secara umum rata-rata pengeluaran untuk petani pemilik, penyewa dan penyakap akan diuraikan di bawah ini seperti tampak pada Tabel 5.

Sedangkan rata-rata pengeluaran untuk petani pemilik, penyewa dan penyakap akan diuraikan di bawah ini seperti tampak pada Tabel 6.

Tabel 5. Rata-Rata Biaya Penggunaan Faktor-Faktor Produksi Setiap Hektar Pada Musim Penghujan (Dalam Rupiah)

\begin{tabular}{|c|l|r|r|r|}
\hline No & \multicolumn{1}{|c|}{ Faktor Produksi } & Pemilik & \multicolumn{1}{c|}{ Penyewa } & \multicolumn{1}{c|}{ Penyakap } \\
\hline 1 & Benih & $108.836,00$ & $71.229,17$ & $48.348,00$ \\
\hline 2 & Pupuk Urea & $279.434,93$ & $133.333,33$ & $97.880,00$ \\
\hline 3 & Pupuk TSP & $42.739,73$ & $26.608,33$ & $24.423,36$ \\
\hline 4 & Pupuk lain & $28.061,64$ & $20.312,50$ & $15.599,92$ \\
\hline 5 & Pestisida & $94.123,29$ & $52.270,80$ & $36.580,00$ \\
\hline 6 & Tenaga Kerja & $1.557 .746,6$ & $841.375,00$ & $600.560,00$ \\
\hline
\end{tabular}

Sumber: Data Primer diolah, 2009

Tabel 6. Rata-Rata Biaya Penggunaan Faktor-Faktor Produksi Setiap Hektar Pada Musim Kemarau (Dalam Rupiah)

\begin{tabular}{|c|l|l|l|l|}
\hline No & \multicolumn{1}{|c|}{ Faktor Produksi } & \multicolumn{1}{|c|}{ Pemilik } & \multicolumn{1}{c|}{ Penyewa } & \multicolumn{1}{c|}{ Penyakap } \\
\hline 1 & Benih & $109.041,00$ & $71.354,20$ & $45.068,00$ \\
\hline 2 & Pupuk Urea & $308.561,60$ & $139.000,00$ & $105.680,00$ \\
\hline 3 & Pupuk TSP & $56.438,35$ & $36.608,33$ & $30.023,36$ \\
\hline 4 & Pupuk lain & $32.239,73$ & $19.854,16$ & $16.799,92$ \\
\hline 5 & Pestisida & $85.417,80$ & $92.792,00$ & $36.060,00$ \\
\hline 6 & Tenaga Kerja & $1.482 .512,30$ & $815.708,33$ & $569.800,00$ \\
\hline
\end{tabular}

Sumber: Data Primer diolah, 2009 


\section{Analisis Fungsi Produksi}

Untuk melakukan estimasi fungsi produksi usahatani padi dipergunakan fungsi produksi CobbDouglas. Karena usahatani padi dilakukan baik pada musim kemarau dan musim penghujan, maka estimasi fungsi produksi juga dibedakan untuk musim penghujan dan kemarau. Hasil estimasi fungsi produksi Cobb-Douglas untuk musim penghujan dan musim kemarau. Analisis fungsi Cobb-Douglass untuk musim penghujan dapat dilihat pada Tabel 7.

\section{Tabel 7. Estimasi Fungsi Produksi Cobb-Douglas Usahatani Padi Antar Status Penguasaan lahan Pada Musim Penghujan}

\begin{tabular}{|l|l|l|}
\hline Peubah LN & Koefisien Regresi & T hitung \\
\hline Benih & 0.334 & 0.837 \\
Urea & 0.317 & 1.242 \\
TSP & 0.200 & $2.343^{* * *}$ \\
Pupuk lainnya & 0.133 & $1.751^{*}$ \\
Pestisida & 0.206 & 1.554 \\
Tenaga kerja & 0.533 & $1.972^{*}$ \\
Luas lahan & 0.745 & $1.781^{*}$ \\
Pengeluaran lain & -0.020 & -0.287 \\
Dumy Pemilik & 0.185 & 0.642 \\
Dumy Penyewa & 0.337 & 1.017 \\
konstanta & 16.949 & 8.462 \\
\hline F hitung & 2.946 & \\
R2 & 0.211 & \\
\hline
\end{tabular}

Sumber: Data Primer diolah, 2009

Keterangan:

*) : Signifikan pada $\alpha=10 \%(1,658)$

**) $\quad$ : Signifikan pada $\alpha=5 \%(1,980)$

***) : Signifikan pada $\alpha=1 \%(2,167)$

Hasil estimasi Cobb-Douglas pada musim hujan menghasilkan $\mathrm{F}$ hitung yang signifikan, hal ini berarti bahwa model yang dipakai cocok, karena semua variabel bebas yang dimasukkan dalam model penting dalam menjelaskan variabel terikatnya. Jika dilihat secara parsial, terdapat empat variabel dependen yang signifikan mempengaruhi variabel independennya, yakni jumlah pupuk TSP, jumlah pupuk lainnya, jumlah tenaga kerja, dan luas lahan. Hal ini berarti semakin banyak jumlah pupuk TSP dan pupuk lainnya yang digunakan dalam usaha tani maka jumlah produksi yang dihasilkan akan meningkat asalkan penggunaan jenis-jenis pupuk tersebut tidak melebihi dari standar yang telah ditentukan. Seiring dengan hal tersebut maka semakin luas lahan garapan maka produksi yang diperolehpun juga akan meningkat.

Berdasarkan hasil perhitungan dapat dilihat juga bahwa terdapat 4 variabel independen yang tidak signifikan pengaruhnya. Variable tersebut antara lain jumlah benih padi, jumlah pupuk urea, jumlah pestisida dan pengeluaran lain. Beberapa alasan penggunaan pupuk urea tidak significan dalam penelitian ini adalah apabila pupuk urea digunakan pada saat kondisi tanah kering dapat menyebabkan akar tanaman terbakar (Puspitasari, 2008). Hal ini juga senada dengan pendapat Suwalan et al. 2004 dalam Dewi Sahara dan Idris (2005) yang mengatakan bahwa respon tanaman terhadap pemberian pupuk akan meningkat apabila pupuk yang digunakan tepat jenis, dosis, waktu dan cara pemberian.

Begitu pula dengan penggunaan bibit yang tidak signifikan saat musim penghujan, hal ini bisa terjadi karena walaupun jumlah benih terus ditambah sementara frekuensi hujan turun sering, benih bisa hanyut terbawa arus air, sehingga semakin banyak jumlah bibit yang digunakan belum tentu produksi yang digunakan meningkat. Senada dengan hal diatas jumlah pestisida juga tidak signifikan, hal ini mungkin disebabkan karena tanaman padi tidak selalu bergantung dengan pestisida. Biasanya bila ada hama maka tanaman disemprot dan bila tidak ada hama pestisida belum tentu digunakan oleh para petani. Sementara itu untuk hasil analisis fungsi Cobb-Douglass untuk musim kemarau dapat lihat pada Tabel 8.

\section{Tabel 8. Estimasi Fungsi Produksi Cob-Douglas Usahatani Padi Pada Musim Kemarau}

\begin{tabular}{|l|l|l|}
\hline \multicolumn{1}{|c|}{ Peubah LN } & Koefisien Regresi & \multicolumn{1}{|c|}{ T hitung } \\
\hline Benih & 0.345 & $3.755^{* * *}$ \\
Urea & 0.220 & $2.382^{* * *}$ \\
TSP & 0.016 & 0.872 \\
Pupuk lainnya & 0.019 & 1.174 \\
Pestisida & 0.047 & 1.494 \\
Tenaga kerja & 0.155 & $2.445^{* * *}$ \\
Luas lahan & 0.514 & $5.301 * * *$ \\
Pengeluaran lain & 0.021 & 1.292 \\
Dumy Pemilik & 0.030 & 0.458 \\
Dumy Penyewa & 0.084 & 1.074 \\
konstanta & 6.957 & 14.577 \\
\hline F hitung & 78.076 & \\
R & 0.865 & \\
R2 & 0.876 & \\
\hline
\end{tabular}

Sumber:data primer diolah,2009

Keterangan:

$\begin{array}{ll}*) & \text { Signifikan pada } \alpha=10 \%(1,658) \\ * *) & : \text { Signifikan pada } \alpha=5 \%(1,980) \\ * * *) & : \text { Signifikan pada } \alpha=1 \%(2,167)\end{array}$ 
Hasil estimasi dengan fungsi produksi CobbDouglas seperti tertera dalam table di atas menghasilkan $\mathrm{F}$ hitung yang signifikan, hal ini berarti bahwa model yang dipakai cocok, karena semua variabel bebas yang dimasukkan dalam model adalah penting dalam menjelaskan variabel terikatnya. Hal ini ditunjang oleh besarnya koefisien determinasi yang diperoleh dari hasil penghitungan yaitu sebesar R2 $=0,8765$, yang berarti bahwa variabel bebas yang dipakai dalam model tersebut telah dapat menjelaskan variabel terikatnya sekitar 87 persen lebih dan sisanya sebesar 13 persen dijelaskan oleh variable diluar model.

Berdasarkan hasil perhitungan dapat dilihat juga bahwa terdapat 4 variabel independen yang tidak significan pengaruhnya. Variable tersebut antara lain pupuk lainnya, pupuk TSP, jumlah pestisida dan pengeluaran lainnya. Penggunaan pupuk TSP yang tidak signifikan ini dipengaruhi oleh kondisi lahan pertanian di tempat penelitian telah memenuhi unsur hara yang terkandung didalam tanah terutama unsure $\mathrm{P}$ atau phosphor. Senada dengan hal diatas jumlah pestisida juga tidak signifikan, hal ini mungkin disebabkan karena tanaman padi tidak selalu bergantung dengan pestisida. Biasanya bila ada hama maka tanaman disemprot dan bila tidak ada hama pestisida belum tentu digunakan oleh para petani.

Jika melihat variabel boneka (dummy) yang digunakan, variabel ini tidak berpengaruh secara nyata artinya tingkat produksi petani pemilik, penyewa, dan penyakap adalah relatif sama, sehingga subhipotesis 1a ditolak.

\section{Analisis Fungsi Keuntungan}

Model yang dipergunakan dalam analisis fungsi keuntungan adalah model dari cob-douglass seperti tekah dikemukakan. Dari model fungsi keuntungan tersebut dapat dicari perbandingan efisiensinya. Karena usahatani padi dilakukan baik pada musim kemarau maupun musim penghujan, maka estimasi fungsi keuntungan terbagi menjadi dua yaitu untuk musim kemarau dan musim penghujan. Estimasi fungsi keuntungan untuk musim penghujan dapat dilihat dalam Tabel 9.
Tabel 9. Estimasi fungsi keuntungan Model CobbDouglas Usahatani Padi Antar Status Penguasaan lahan pada Musim Penghujan

\begin{tabular}{|l|l|l|}
\hline \multicolumn{1}{|c|}{ Peubah LN } & Koefisien Regresi & \multicolumn{1}{c|}{ T hitung } \\
\hline Benih & -0.203 & $-1.794^{*}$ \\
Urea & -0.041 & $-1.691^{*}$ \\
TSP & -0.016 & -0.685 \\
Pupuk lainnya & -0.043 & $-2.096^{* *}$ \\
Pestisida & -0.031 & -0.863 \\
Tenaga kerja & -0.324 & $-4.332^{* * *}$ \\
Luas lahan & -0.570 & $-5.011^{* * *}$ \\
Pengeluaran lain & -0.012 & -0.666 \\
Dumy Pemilik & -0.013 & 1.393 \\
Dumy Penyewa & -0.032 & 1.143 \\
konstanta & 14.010 & -25.986 \\
\hline F hitung & 72.174 \\
R & 0.830 & \\
R2 & 0.842 \\
\hline
\end{tabular}

Sumber:data primer diolah,2009

Keterangan:

$$
\begin{array}{ll}
*) & : \text { Signifikan pada } \alpha=10 \%(1,658) \\
* *) & : \text { Signifikan pada } \alpha=5 \%(1,980) \\
* * *) \quad: \text { Signifikan pada } \alpha=1 \%(2,167)
\end{array}
$$

Hasil estimasi dengan fungsi produksi CobbDouglas seperti tertera dalam tabel di atas menghasilkan F hitung yang signifikan yang berarti bahwa model yang dipakai sesuai sesuai, karena semua variabel bebas yang dimasukkan dalam model penting dalam menjelaskan variabel terikatnya. Hal ini ditunjang oleh besarnya koefisien determinasi yang diperoleh yaitu sebesar 0,842 , yang berarti bahwa variabel bebas yang dipakai dalam model tersebut telah dapat menjelaskan variabel terikatnya sekitar 84 persen, sisanya sebesar 16 persen dijelaskan oleh variabel di luar model..

Dari elastisitas yang ditunjukkan dapat dikatakan bahwa dengan adanya kenaikan pengeluaran untuk membeli benih maka keuntungan yang diperoleh mengalami penurunan sebesar 20 persen. Begitu pula dengan penggunaan pupuk urea, pupuk lain dan luas lahan, semakin banyak petani menggunakan ketiga factor produksi tersebut maka keuntungan yang diperoleh akan mengalami penurunan sebesar elastisitas masing-masing faktor produksi.

Sedangkan untuk fungsi keuntungan pada musim kemarau dapat dilihat dalam tabel 10 berikut ini. 
Tabel 10. Estimasi fungsi keuntungan Model Cobb-Douglas Usahatani Padi Antar Status Penguasaan lahan pada Musim Kemarau

\begin{tabular}{|l|l|l|}
\hline \multicolumn{1}{|c|}{ Peubah LN } & Koefisien Regresi & \multicolumn{1}{c|}{ t hitung } \\
\hline Benih & -0.289 & $-2.983^{* * *}$ \\
Urea & -0.016 & $-1.761^{*}$ \\
TSP & -0.009 & -0.985 \\
Pupuk lainnya & -0.004 & -0.496 \\
Pestisida & -0.079 & $-2.197 * * *$ \\
Tenaga kerja & -0.069 & -1.250 \\
Luas lahan & -0.962 & $-9.613^{* * *}$ \\
Pengeluaran lain & -0.175 & $-6.755^{* * *}$ \\
Dumy Pemilik & -0.025 & -1.201 \\
Dumy Penyewa & -0.041 & -1.024 \\
konstanta & 16.591 & 14,476 \\
\hline F hitung & 47.330 & 0.755 \\
R & 0,771 & R2 \\
Sumber:data primer diolah,2009 \\
Keterangan: : Signifikan pada $\alpha=10 \%(1,658)$ \\
*) : Signifikan pada $\alpha=5 \%(1,980)$ \\
**) : Signifikan pada $\alpha=1 \%(2,167)$ \\
***)
\end{tabular}

Hasil estimasi dengan fungsi produksi CobbDouglas seperti tertera dalam tabel di atas menghasilkan F hitung yang signifikan yang berarti bahwa model yang dipakai cocok, karena semua variabel bebas yang dimasukkan dalam model berperan penting dalam menjelaskan variabel terikatnya. Hal ini ditunjang oleh besarnya koefisien determinasi yang diperoleh yaitu sebesar 0,771, yang berarti bahwa variabel bebas yang dipakai dalam model tersebut telah dapat menjelaskan variabel terikatnya sekitar 77 persen lebih dan 23 persen sisanya dijelaskan oleh variabel diluar model.

Jika dilihat secara parsial, terdapat lima variabel independen yang signifikan mempengaruhi variabel dependennya, yakni harga benih padi, urea, harga pestisida, luas lahan dan pengeluaran lainnya. Variabel yang secara nyata berpengaruh tersebut, juga menunjukkan elastisitas keuntungannya, untuk harga benih padi $-0,289$, harga pestisida $-0,079$, luas lahan $-0,962$, dan pengeluaran lainnya $-0,175$. Dari elastisitas yang ditunjukkan dapat dikatakan bahwa dengan adanya kenaikan pengeluaran untuk membeli benih maka keuntungan yang diperoleh mengalami penurunan sebesar 28 persen. Begitu pula dengan peningkatan penggunaan pestisida yang dampaknya akan menurunkan keuntungan sebesar 7 persen. Penggunaan pupuk lain dan luas lahan juga memperlihatkan hal yang sama, semakin banyak petani menggunak- an ketiga faktor produksi tersebut maka keuntungan yang diperoleh akan mengalami penurunan sebesar elastisitas masing-masing faktor produksi.

\section{Distribusi Pendapatan}

\section{Distribusi Pendapatan Secara Relatif}

Berdasarkan data yang ada dapat diketahui bahwa dari total 120 jumlah petani, yang memiliki lahan kurang dari 1 Ha yaitu sebanyak 112 orang, dan ini merupakan proporsi terbesar dalam struktur total penguasan lahan di daerah penelitian. Satu petani (responden) tidak dimasukkan kedalam distribusi pendapatan diatas karena petani tersebut memliki pendapatan negatif (minus).

Pendapatan sebelum adanya pendapatan sampingan tersebut diklasifikasikan berdasarkan nilai pendapatan yang didapat dari selisih antara penerimaan petani dari dua kali masa panen (musim penghujan dan musim kemarau) dengan total biaya yang dikeluarkan selama dua kali masa panen tersebut. Berbeda dengan distribusi pendapatan relatif sebelum adanya pendapatan sampingan, dapat diketahui bahwa setelah adanya pendapatan sampingan maka pendapatan petani pun akan meningkat.

\section{Tabel 11. Index Gini Keseluruhan Responden}

\begin{tabular}{|c|c|}
\hline $\begin{array}{c}\text { Index Gini Pendapatan } \\
\text { Pertanian Sebelum Adanya } \\
\text { Pendapatan diluar Pertanian }\end{array}$ & $\begin{array}{c}\text { Index Gini Pendapatan } \\
\text { Pertanian Setelah Adanya } \\
\text { Pendapatan diluar Pertanian }\end{array}$ \\
\hline 0,502354148 & 0,484039741 \\
\hline
\end{tabular}

Sumber:data primer diolah, 2009

Berdasarkan perhitungan index gini pada Tabel 11 menunjukkan bahwa ketika terdapat pendapatan diluar hasil pertanian, ketimpangan pendapatan menjadi lebih kecil. Dari perubahan angka index tersebut dapat disimpulkan bahwa adanya pendapatan diluar pertanian mampu meningkatkan pendapatan total.

\section{KESIMPULAN DAN SARAN}

\section{Kesimpulan}

Hasil penelitian dari pengolahan data dapat ditarik kesimpulan sebagai berikut: Efesiensi dan tingkat produksi petani penyakap tidak lebih buruk dibandingkan dengan petani pemilik penggarap dan petani penyewa. Pada musim kemarau petani penyakap 
mempunyai tingkat produksi dan efesiensi yang relatif sama dengan petani pemilik penggarap, Strategi yang digunakan petani penyakap untuk menutupi kelemahan dalam posisi ekonomi ketika harus meningkatkan tingkat produksi dan efesiensi ekonomi adalah dengan memakai tenaga keluarga yang banyak sehingga dapat menekan total biaya, Status penguasaan lahan mempuyai pengaruh terhadap distribusi pendapatan, petani yang mempunyai penguasaan lahan lebih luas cenderung mempunyai pendapatan yang lebih besar dibanding penguasaan lahan yang lebih sempit.

Tingkat ketimpangan pendapatan petani tanpa pendapatan di luar pertanian relatif lebih tinggi dibandingkan ketimpangan pendapatan petani yang telah memasukan pendapatan dari luar pertanian, Pendapatan petani di luar hasil pertanian mempunyai mengurungi ketimpangan pendapatan.

Produktivitas usahatani dapat dinaikan dengan menambah pemakaian beberapa sarana produksi,

\section{DAFTAR PUSTAKA}

Adisasmita, Raharjo. 2006. Pembangunan pedesaan dan perkotaan. Graha Ilmu: Yogyakarta.

Adam, D.W. and N. Rask. 1968. Economic of Costshare Leases in Less Developed Countries, American Journal of Agricultural Economic. 50:1

Arifin, DR. Bustanul. 2004. Analisis ekonomi Pertanian Indonesia. Penerbit Buku Kompas: Jakarta.

Bardhan, P.K. and T.N. Srinivasan. 1971. Cropsharing Tenancy in Agriculture. Theoretical and empirical Analysis. American Economic Review. 52:3

Cheung, Steven N.S. 1969. The Theory of Share Tenancy. Chicago: The University of Chicago Press.

Esmara, Hendra. 1977. Proyeksi Pembagian Pendapatan dan Kemiskinan di Indonesia pada Tahun 2000. Padang: Lembaga Penelitian Ekonomi Regional Fakultas Ekonomi Universitas Andalas.

Fujimoto, Akimi. 1983. Income Sharing among Malay Peasants: A Study of Land Tenure and Rice Productions Singapore. Singapore: University Press.

Geertz, Clifford. 1963. Agricultural Involution The Process of Ecologycal Chenge. Berkeley : University of California Press.

Henderson, James M. and Richard E. Quandt. 1988. Microeconomic Theory a Methematical Approach. Singapore: Mc Graw Hill Book Co.

Hidayat. 1986. Konsep Dasar dan Pengertian Produktivitas serta Intepretasi Hasil Pengukurannya. Prisma, November 1986. khususnya menambah pemakaian beberapa sarana produksi, terutama pemakaian pupuk urea, benih dan luas lahan, Kenaikan tingkat keuntungan usahatani padi dapat dinaikan dengan menurunkan beberapa harga sarana produksi seperti benih, urea, pestisida, serta luas lahan.

\section{Saran}

Para petani baik petani pemilik penggarap. Penyewa dan penyakap jika mengandalkan pendapatan dari padi kebanyakan mempnyai pendapatan yang relati kecil (miskin) dan ketimpangannya lebih besar jika dibandingkan sesudah memasukan pendapatan dari luar pertanian. Oleh karena itu pembangunan pedesaan perlu dilakukan dengan menambah dan memperbaiki infrastruktur di pedesaan sehingga petani mempunyai pendapatan sampingan diluar pertanian.

Kano, Hiroyoshi. 1977. Sistem Pemilikan Tanah dan Masyarakat Desa di Jawa pada Abad XIX. dalam Soediono M.P Tjondronegoro dan Gunawan Wiradi. 1984. Dua Abad Penguasaan Tanah. Jakarta. Gramedia.

Kikuchi, M. and Y. Hayami. 1981. Asian Village Economy at the Crossroad an Economy Approach to Institutional Change. Tokyo: University of Tokyo Press.

Kogiku, K.C. 1971. Microeconomic Models. New York: Harper \& Row.

Kuznets, Simon S. 1933. "National Income" in The American Economic Assosiation. 1955. Reading in the Theory of Income Distribution. Philadelphia: The Blakiston Company.

Marshall, Alfred. 1959. Principles of Economics. London: Macmillan \& Co. Ltd.

Mirer, Thad W. 1988. Economic Statistics and Econometrics. New York: Mcmillan Publishing Company.

Miller, R.J and Roger E Meiners. 2000. Teori mikroekonomi intermediate. Pt Raja Grafindo Persada: Jakarta.

Mubyarto. 1985. "Pendahuluan" dalam Mubyarto (ed). 1985. Peluang Kerja dan Berusaha di PEdesaan. Yogyakarta: BPFE dan P3PK UGM.

Nuhung, Iskandar Adi. 2006. Bedah Terapi Pertanian Nasional. Bhuana Ilmu Popular kelompok gramedia: Jakarta

Roll, Werner. 1976. Struktur Pemilikan Tanah di Indonesia 
Studi kasus Daerah Surakarta, Jawa Tengah. Terjemahan Jane Tjan. Jakarta: Rajawali.

Sawit, M. Husen. 1985. Status Penguasaan Tanah di Usaha Tanni padi dan Implikasi Ekonominya: Sebuah Studi di Pedesaan Jawa Barat. EKI, Vol. XXXIII, No. 1, Maret 1985.

Semaoen, Iksan. 1992. Ekonomi Produksi Pertanian Teori dan Aplikasi. Jakarta: ISEI.

Siahaan, Hotman M. 1980. Tekanan Struktural dan Mobilitas Petani di Pedesaan. Prisma, No.1 Januari 1980.

Soejono, Irlan. 1977. Growth and Distributional Changes of Paddy Farm Income in Central Java 19681974. Dissertation. Ames: Iowa State University.

Soekartawi. 1984. Farm Resource- Allocation and Efficiency of Javanese Agriculture. Desertation. Armide: University of new England.

Soekartawi. 1990. teori Ekonomi Produksi dengan Pokok Bahasan Analisis Fungsi Cobb Douglas. Jakarta: Rajawali Pers.
Sugeng, HR. 1989. Bercocok Tanam Padi. Semarang: Aneka Ilmu.

Suhendar, Endang. 1994. Pemataan Pola-Pola Sengketa Tanah di Jawa Barat. Bandung: Akatiga.

Wie, Thee Kian. 1983. Pembangunan Ekonomi dan Pemerataan, Beberapa Pendekatan Alternatif. Thee Kian Wie (ed). 1983. Pembangunan Ekonomi dan Pemerataan, Beberapa Pendekatan Alternatif. Jakarta: LP3ES.

Wirasasmita, Yuyun. 1991. Fungsi Produksi: Perkembangan dan Aplikasinya. Paper Kuliah Perdana Program Pascasarjana Universitas Padjadjaran, 6 September 1991.

1978. Metodologi Penelitian Distribusi Pendapatan di Pedesaan. Perhepi. 1978. Pola Pembangunan Pertanian dan Pedesaan dalam Pelita III. Jakarta: Yayasan Agro Ekonomika. 